Early Modern Women:

An Interdisciplinary Journal

2012, vol. 7

\title{
True Fire, Noble Flame: Friendship Poetry by Katharina Lescailje, Cornelia van der Veer, and Katherine Philips
}

\section{Martine van Elk}

Tn early modern Europe, friendship poetry by women was an interna1 tional phenomenon. Women wrote poems to female friends in England, Spain, Italy, France, and the Dutch Republic. Surprisingly few cross-cultural analyses of such poems have been done, even though they provide a perfect opportunity to explore how and why women used specific literary forms in different cultural and socio-political environments. ${ }^{1}$ This essay compares friendship poems by two Dutch women writers, Katharina Lescailje and Cornelia van der Veer, with the work of Katherine Philips, the best-known English proponent of the genre. What makes this comparison compelling is that both Dutch and English women used friendship poems to reflect on and respond to two interrelated developments: the transition from a traditional to a modern understanding of the relation between public and private and the emergence of a public sphere.

In the seventeenth century, both England and the Dutch Republic experienced revolutions, accompanied by a profound questioning of royal absolutism. In The Secret History of Domesticity, Michael McKeon argues that the "devolution" of royal absolutism brought about the birth of the

1 Dianne Dugaw and Amanda Powell have compared the friendship poems of Katherine Philips and Aphra Behn with those of Iberian poets, in "Sapphic SelfFashioning in the Baroque Era: Women's Petrarchan Parody in English and Spanish," Studies in Eighteenth Century Culture 35 (2006): 127-60. 
public sphere in England along with a gradual shift from a traditional view of public and private as distinct but continuous to a modern view of public and private as separate and opposing, a process he describes as "a progressive detachment of the normatively absolute from its presumed locale in royal absolutism and its experimental relocation in 'the people,' the family, women, the individual, personal identity, and the absolute subject." ${ }^{2}$ In this context, an ideology of domesticity was formed as the household "gradually became the seat of primary socialization, of Puritan discipline and gentle cultivation, through which it took on those nonprivative private values that we associate with the ethos of the domestic sphere." Even though public and private came to be seen as opposing concepts, they were deeply implicated in each other. McKeon relies on the theories of Jürgen Habermas to argue for a dialectical relationship between public and private, characterized as "an opposition that is also an interpenetration." The instability of the two terms, on the cusp between two radically different ways of understanding them, was particularly important to seventeenth-century women, who had been traditionally denied a public voice and who were increasingly associated with the new ideology of domesticity.

Women writers in England and the Dutch Republic, I will argue, found in friendship poetry an ideal form in which to respond to and reflect on women's changing place in society. After all, friendship poetry had long been a genre that merged the private and the public. Ever since classical antiquity, the genre had combined an interest in the civic importance of friendship with eroticism and platonic desire. This flexibility appealed to women, who had been afforded opportunities for politically motivated expression. During the Dutch Revolt against Spain (1566-1609) and the

${ }^{2}$ Michael McKeon, The Secret History of Domesticity: Public, Private, and the Division of Knowledge (Baltimore: The Johns Hopkins University Press, 2005), xxii.

3 Ibid, 10.

${ }^{4}$ Ibid., 48. Although McKeon denies the need for the concept of "counterpublics," or smaller public spheres in which voices of dissent and opposition are heard (73), it serves as a useful reminder that there were overlapping areas of public identity for women during this period. Catharine Gray has made the case for reading Philips's work as part of a royalist counterpublic. See Women Writers and Public Debate in Seventeentb-Century Britain (New York: Palgrave Macmillan, 2007), chap. 3. 
English Civil War (1642-51), the two countries saw a rise in pamphlet publication by men and women and a new sense of the importance of public opinion in response to political upheavals. ${ }^{5}$ Even though women writers continued to face obstacles to publication, the printing press was becoming more open to women, especially in the second half of the seventeenth century.

This essay argues that Dutch and English friendship poetry by women responded negatively to the separation of the public and private spheres and, perhaps unexpectedly, to the emerging public sphere. Instead, they imagine a utopian public realm ruled by women, in which dissent and conflict are absent. This fantasy, at times presented tongue-in-cheek, takes its inspiration from absolutist ideology, in which rule theoretically happens by universal consent rather than by rational debate. In this imagined return to a world before the decline of absolutism, public and private are in harmony. Once friendship is betrayed, however, public and private divide, and women are faced with deprivation and loss of status, both early meanings of the term "privacy." Even though these poems hark back nostalgically to a pre-revolutionary public sphere, they aim to articulate a place for women

${ }^{5}$ Habermas dates the emergence of the public sphere in England to the Glorious Revolution. Much recent work has claimed that it emerged earlier, out of the conflicts and controversies of the Civil War. Peter Lake and Steven Pincus go even further, asserting that there was a public sphere from the Reformation onward. There also existed a lively public sphere in the Dutch Republic from the beginning of the seventeenth century as a consequence of the Revolt against Spain, which was followed by a tremendous increase in pamphlet publication and a new sense of the importance of public opinion. See Jürgen Habermas, The Structural Transformation of the Public Sphere: An Inquiry into a Category of Bourgeois Society, trans. Thomas Burger (Cambridge, MA: MIT Press, 1989); Lake and Pincus, "Rethinking the Public Sphere in Early Modern England," in The Politics of the Public Sphere in Early Modern England, ed. Peter Lake and Steven Pincus (Manchester: Manchester University Press, 2007), 1-30, and Jonathan I. Israel, The Dutch Republic: Its Rise, Greatness, and Fall, 1477-1806 (Oxford: Clarendon Press, 1995), 565.

6 I am mindful of the different early modern meanings of the word "private," which, according to Erica Longfellow, primarily meant either "not public" or "secret," rather than being associated with personal rights. See her "Public, Private, and the Household in Early Seventeenth-Century England," The Journal of British Studies 45, no. 2 (2006): 31334, 333. See also Ronald Huebert, "The Early Social History of a Word," The Sewanee Review 105, no. 1 (1997): 21-38. Huebert recognizes four clusters of meaning for the 
in the public realm as exemplary of certain important virtues. After briefly sketching the relevant critical and historical context for these friendship poems, I will explore Lescailje and Van der Veer first, using their poems to shed new light on the much more elaborately analyzed work of Philips. I do not claim to offer a full discussion of Philips, whose representation of friendship takes multiple, complex, and ambiguous forms, as it draws on a range of discourses about women, including neo-Platonic love poetry, pastoral romance, ancient myth, alchemy, religion, and politics. Instead, I will focus on one particular type of fantasy encountered in both Dutch and English friendship poems, explaining that fantasy as a response to the transition from a traditional to a modern view of public and private.

Recent criticism has been mostly concerned with whether Dutch friendship poems by women articulate same-sex desire between women.? Philips has long been analyzed along the same lines but is increasingly being treated from a political perspective. Carol Barash, Hero Chalmers, Catharine Gray, and others read her representations of harmony and union in friendship as veiled articulations of her royalism. ${ }^{8}$ The division between analyses of Philips's poems as private expressions of desire and as

word "private," associated with a lack of status, private property, secrecy, and interiority, complicating Longfellow's argument.

7 The two main points of view in the debate have been articulated by Lia van Gemert and Ellen Grabowsky. See Van Gemert, "Hiding Behind Words? Lesbianism in 17th-Century Dutch Poetry," Thamyris 2 (1995): 11-44, and "De vrouwenzucht van Katharina Lescailje," in Klinkend boeket: Studies over Renaissancesonnetten voor Marijke Spies, ed. Henk Duits et al. (Hilversum: Verloren, 1994), 143-49; Ellen Grabowsky, "Katharina Lescailje (1649-1711) en de 'vrouwenzucht': Schijn of werkelijkheid?" Mededelingen van de Stichting Jacob Campo Weyerman 23, no. 2 (2000): 65-79, 76. See also Marijke Spies, "Oudejaarsavond 1675. Cornelia van der Veer schaduwt Katharina Lescailje als deze van het huis van haar vriendin Sara de Canjoncle naar dat van haar zuster gaat. Het vrouwelijk aandeel," Nederlandse Literatuur, een Geschiedenis, ed. M. A. Schenkeveld-van der Dussen (Groningen: Noordhoff, 1993), 282-87, and Myriam Everard, "De liefde van Lesbos in Nederland: Sappho in de Nederlandse letteren van $19 \mathrm{e}$ en begin 20e eeuw," Tijdschrift voor Vrouwenstudies 5.5 (1984), 333-50, 338-40.

8 See Carol Barash, English Women's Poetry, 1649-1714: Politics, Community, and Linguistic Authority (Oxford: Clarendon Press, 1996), chap. 2; Hero Chalmers, Royalist Women Writers, 1650-1689 (Oxford: Clarendon Press, 2004), chaps. 2 and 3, and Gray, Women, chap. 3. 
political allegory points to the problem of determining their place in relation to the public and private spheres. Celia Easton and Elizabeth Wahl, for example, argue that Philips's poetry disguises her private lesbian desires with a publicly respectable, platonic exterior that presents her love for other women as virtuous, chaste, and innocent. 'Such readings, however, risk imposing on the poetry anachronistic distinctions between public and private, which, after all, were still developing in the period. Rather than reading friendship poetry as primarily public or private, we need to explore it in light of what McKeon sees as a dialectical relationship between the two. Both Barash and Gray have noted that Philips used friendship poetry to suggest reforming the public sphere along the lines of female friendship, although Gray places more emphasis on the poetry as positing equality between women whereas Barash is more concerned with the platonic worship of the female friend, linked to the absent king. Both these approaches are useful to my argument about friendship poetry's fantasy of a return to an absolutist public realm centered on a woman.

Although the Dutch Republic and England witnessed similar political upheaval, a number of social and cultural contexts specific to each nation affected women differently. First, especially in the province of Holland, the aristocracy and the court were less politically and culturally influential than they were in England before and after the Civil War, and Dutch regents (professional administrators and magistrates) were in charge for much of the century. Dutch women writers tended to come from the wealthier middle class, including regent backgrounds, with elite aspirations; English women writers were usually aristocratic or of the gentry. Second, literacy rates were higher in the more urbanized Dutch Republic than in England, including among women, and a greater number of Dutch women ran businesses and engaged in trade than their English counterparts, partly due to the frequent absence and death of sea-faring

9 See Elizabeth Susan Wahl, Invisible Relations: Representations of Female Intimacy in the Age of Enlightenment (Stanford: Stanford University Press, 1999), chap. 4, and Celia Easton, "Excusing the Breach of Nature's Laws: The Discourse of Denial and Disguise in Katherine Philips's Friendship Poetry," Restoration 14 (1990): 1-14. 
husbands..$^{10}$ Third, the toleration, however limited, of different religions in the Low Countries, especially after 1630, meant that, unlike in England, women of different religious affiliations could engage with each other in writing. Fourth, in the Low Countries, literary production was stimulated through networks and coteries, as well as the older chambers of rhetoric, rather than through patronage. Mid- to late-seventeenth-century English women, who also commonly produced their works in and for a coterie, tended to be affiliated more strongly than many writing Dutch women with particular political groupings, whether Royalist or sectarian. Finally, marriage was perceived in the Low Countries as incompatible with writing. ${ }^{11}$ There were very few women who produced anything in writing once they had married. As Riet Schenkeveld-van der Dussen writes in an anthology of early modern Dutch women's writing, "Women realised all too well that by marrying they would shut themselves away and deny themselves the freedom to practise the arts." ${ }^{, 12}$ Famous authors like Anna Roemers Visscher and Catharina Questiers abruptly stopped publishing after marriage, while women writers with long careers, like Anna Maria van Schurman, Lescailje, and Van der Veer, remained unmarried. Marriage and especially having children were seen as no longer allowing for the kind of leisure time middle-class women needed in order to write. While there may have been practical reasons for the lack of creative output by married women, this cultural injunction shows the limits of the Dutch acceptance of a female presence in the public sphere. English women faced no such specific expectation, perhaps partly due to their higher social and economic

10 A useful overview of the position of women in the Dutch Republic is provided in E. M. Kloek, "De vrouw," Gestalten van de Gouden Eeuw: Een Hollands groepsportret, ed. H. M. Beliën et. al. (Amsterdam: Bert Bakker, 2005), 241-80. For an analysis of women's presence in commerce, see Danielle van den Heuvel, Women and Entrepreneurship: Female Traders in the Northern Netherlands c. 1580-1815 (Amsterdam: Askant, 2007).

11 See the introduction to the landmark anthology, Met en zonder lauwerkrans. Schrijuende vrouwen uit de vroegmoderne tijd 1550-1850: Van Anna Bijns tot Elise van Calcar, ed. Riet Schenkeveld-van der Dussen et al. (Amsterdam: Amsterdam University Press, 1997), 39-43.

12 Women's Writing from the Low Countries, 1200-1875: A Bilingual Anthology, ed. Lia van Gemert et al. (Amsterdam: Amsterdam University Press, 2011), 53. 
status, as we see in the case of well-known married authors like Mary Sidney Herbert, Margaret Cavendish, and Philips.

Katharina Lescailje (1649-1711) lived in a fairly tolerant middleclass milieu in Amsterdam. After her father's death in 1679, she ran her family's book printing and selling business. ${ }^{13}$ The printing house, which was the only company licensed to print for the professional theater in Amsterdam, gave her a place in the literary and artistic circles associated with the theater, allowing for contact with numerous playwrights, such as the famous Joost van den Vondel. Her father, Jacob Lescailje, wrote poetry himself. In this stimulating setting, Katharina apparently began writing as a child, and she gained considerable popularity during her lifetime, especially for her translations of French tragedies. ${ }^{14}$ All of Lescailje's tragedies were regularly performed at the theater in Amsterdam. She remained unmarried, which enabled her to continue writing. As Ellen Grabowsky has noted, Lescailje and her female friends were "used to working, developing themselves intellectually, and going through life independently," a set of circumstances she sees as contributing to a close bond. ${ }^{15}$ Her fame lasted well into the eighteenth century, climaxing in 1731 , when her descendants

${ }^{13}$ According to The Digital Women's Lexicon of the Netherlands (Digitaal Vrouwenlexicon van Nederland), Lescailje probably shared duties with her younger sister, and they were joined by the daughter of their eldest sister at some point. A recent literary history by Karel Porteman and Mieke Smits-Veldt claims that Katharina ran the business with her sister Aletta but does not mention the sister's daughter. Ellen Grabowsky, "Katharina Lescailje," Digitaal vrouwenlexicon van Nederland (Huygens Instituut voor de Nederlandse Geschiedenis), 2010, http://www.historici.nl/Onderzoek/Projecten /DVN/lemmata/data/KatharinaLescailje, Huygens Instituut voor de Nederlandse Geschiedenis (accessed 13 May 2012); Karel Porteman and Mieke B. Smits-Veldt, Een nieuw vaderland voor de muzen: Geschiedenis van de Nederlandse literatuur, 1560-1700, vol. 2 of Geschiedenis van de Nederlandse literatuur, ed. A. J. Gelderblom and A. M. Musschoot (Amsterdam: Bert Bakker, 2008), 780.

14 Lescailje translated a variety of French tragedies, including Nicomède by Pierre Corneille. Philips is of course also known for having translated French plays, specifically Corneille's Pompe and Horace.

${ }^{15}$ Grabowsky, "'vrouwenzucht," esp. 76. All translations from Dutch are mine unless otherwise noted. 
published Dramatic and Mixed Poetry, a three-volume collected edition of her poems and plays.

Lescailje's circle of female friends included a number of women writers, most notably Cornelia van der Veer (1639-1704), who was also a prolific poet. Like Lescailje, she never married, but unlike her co-author, Van der Veer received by her own account little support for her writing in her family. She nevertheless acquainted herself with numerous writers and other prominent Dutch figures. Most importantly, she published a collection of poems with the already well-known poet Catharina Questiers (1631-1669). The book, entitled Battle for the Laurels (1665), contains poems by the two as well as a large number of poems addressed to them by others. ${ }^{16}$ The centerpiece is a ten-poem "battle for the laurels" between the two women, originally written in letters they exchanged over the space of three months in 1662-1663. In these poems, each makes the case that the other should receive the laurels from Apollo for being Amsterdam's best poet. After the publication of the book, Questiers married, making it her final work and a valediction of sorts.

Throughout their careers, both Lescailje and Van der Veer relied on male connections for their literary status. Lescailje's network included her family's clients, the members of the cultural elite who sat on the board of the Amsterdam Theater. Her political poetry must be situated in the context of the conflicts between the regents, the political class that had ruled the Republic and became dominant during the Stadtholderless period from 1650 to 1672 , and the increasingly powerful family of Orange. Nina Geerding has shown that Lescailje's poetry matched that of the poets in her circle in transferring support from the regents to the family of Orange after the watershed Year of Disaster, $1672 .{ }^{17}$ In that year, war had been declared on the Dutch Republic by England and France, and parts of the Republic were invaded. After the shocking murder of the Grand Pensionary Johan

${ }^{16}$ Lauwer-strijt tuschen Catharina Questiers en Cornelia van der Veer. Met eenige bygedichten aan en van baar geschreeven (Amsterdam, 1665). This is the first literary work by two women and one of few seventeenth-century books published at the initiative of women in the Low Countries.

17 Nina Geerding, "Cultural Marketing of William III: A Religious Turn in Katharina Lescailje's Political Poetry," Dutch Crossing 34, no. 1 (2010): 25-41. 
de Wit and his brother, William III successfully assumed power as Stadtholder, returning the country effectively from republican government to something resembling single-ruler government. Lescailjes support for William, couched in Protestant terms, matches Van der Veer's political pamphlets written in the same period, which present Holland as God's chosen land besieged by enemies. ${ }^{18}$ By expressing the political views held by their social circles, Van der Veer and Lescailje not only forged ties with and confirmed their own membership of these circles; they also deliberately engaged in writing a genre of poetry normally reserved for men, making a point of showing that women should have a voice in the public sphere.

The ten friendship poems, seven by Lescailje and three by Van der Veer, that appear in Lescailje's Dramatic and Mixed Poetry date to 16741676. The series follows a specific narrative trajectory, from initial contact, through mutual appreciation, to a feeling of rejection on the part of Van der Veer, and finally a return to more distant praise. The opening poem by Lescailje, set apart from the others in the printed version, is a tribute to Van der Veer and her poetry and expresses the desire for acquaintance. This is followed by two Lescailje poems on the occasion of Van der Veer's trip to Den Briel, one lamenting her departure and one welcoming her back. In the next two poems, Van der Veer thanks Lescailje and praises her as a worthy successor to Questiers, who had died five years earlier. She advises the younger woman to write on Christian subjects, to which Lescailje replies with an extensive discussion of the need to write Christian poetry. In a subsequent poem she modestly denies her resemblance to the great Questiers. Their relationship takes a turn when Lescailje writes a poem to express regret at having forgotten Van der Veer's birthday, followed by perhaps the low point of the friendship, the famous "Complaint to the Very Witty Katherine Lescailje" by Van der Veer. She recounts having shadowed Lescailje on New Year's Eve 1675: after seeing her emerge out of the house of Sara de Canjoncle, another female poet, and in light of her prolonged silence, she questions Lescailje's continued friendship. The last two poems are by Lescailje, the first poem confirming the friendship

${ }^{18}$ Lia Van Gemert,"Vijf vrouwen over oorlog en vrede," Historica 21, no. 1 (1998): 7-9. 
in response to Van der Veer's "Complaint" and excusing her silence by attributing it to modesty, and the second poem written on the occasion of Van der Veer's birthday in 1676. Printed posthumously fifty-five years after they were composed, these poems might be read as merely personal exchanges; in fact, a recent multi-volume work of Dutch literary history describes them as "private poems." ${ }^{19}$ Yet the desire they express for public recognition suggests that Van der Veer and Lescailje envisioned these poems as addressing a larger audience.

We should first note that the friendship between the two writers is articulated in what we would call "public" terms from the outset. They meet as poets and because of their poetry, building their friendship on what they see as their public roles. The public sphere in these poems is fundamentally a literary public sphere rather than a political one. This literary world, a world of conflict and greed, needs to be reformed, they claim, by means of religious poetry. In "To the Artful and Sweet-flowing Poetess Catharina Lescailje," Van der Veer asks Lescailje to become her "companion in art" so that the two of them can combat Momus, the god of Satire, and his "crew."20 To withstand hostile attacks by non-believers, the two women must make themselves strong and prepare for struggle; she claims boldly that her own "neck, of steel, it refuses to bend / To such a yoke." Even though she admits she has sinned by indulging in poetic references to the ancients, she is determined henceforth to write only poetry inspired by Christ. As she asks Lescailje to join her in this task, she warns her that others will judge them severely. They must take care to purify their poetry as "God's boly fount has such delicious liquid / That whosoever tastes her, will let Hippocrene go stale."22 Lescailje responds affirmatively, claiming they are devout virgins with the task of edifying a heathen world. She agrees that they should steer clear of

19 Porteman and Smits-Veldt, Nieuw, 784.

20 Katharina Lescailje, Toneel- en mengelpoezij (Amsterdam, 1731), vol. 1, 335-36. The poem is entitled "Aan de konstige en soetvloeijende dichteresse Catharina Lescailje" and the original words are "kunstgenoot" and "aanhang." I have maintained the original use of italics for Van der Veer's poems.

21 Ibid., 336: "bals, van staal, die weigert zich te buigen / Voor zulk een juk."

22 Ibid., 337: "Godts beylbron beeft soo smaakelyk een voght, / Dat, die haar proeft, laat d'Hipocreen verschalen." Hippocrene is, of course, the ancient source of poetic inspiration. 
poetic investment in Jupiter over Christ and avoid any mingling of Apollo's temple and God's church. With what has been taken as a possible allusion to an erotic relationship, Lescailje tells Van der Veer that they should avoid "the unchaste Sodomite fruit" of poetry inspired by earthly love rather than Christ. ${ }^{23}$ Instead, poetry should be useful, edifying, and devotional. Lescailje associates the public sphere with Mammon, suggesting that it is corrupted by greed. By contrast, "a virgin's quill / Is, just like her honor, so fragile." ${ }^{24}$ This representation of the two poets as Christian virgins in a literary public sphere marked as hostile, mercenary, and heathen sets this series apart from the poems in Battle for the Laurels, in which poetry is treated in ancient terms as religious devotion to Apollo without reference to Christianity. The explanation for this lies probably in Questiers's Catholicism - avoidance of Christian terminology and concentration on the classics allowed Van der Veer and Questiers to ignore the religious controversy that might otherwise have divided them. In these later poems, Lescailje and Van der Veer put themselves forward as Protestant saviors of a male-dominated literary realm that seeks to undermine them, even though doing so might limit their audience, excluding what Van der Veer calls "Those who never saw the light."

This religious outlook provides Lescailje and Van der Veer with a sense of social, cultural, and spiritual superiority that permits them, in spite of potential opposition and the limitations of their birth and gender, to lay claim to a central role in the divisive public sphere in the Dutch Republic in the aftermath of the devastating Year of Disaster. This role is bolstered in the praise poems the women write for each other, in which they construct a utopian version of that public sphere. In their fantasy world, everyone unites in adoration of the female poet. Along with conflict, the divisions between public and private that would restrict women to the domestic sphere are absent. In Lescailje's poem on Van der Veer's depar-

${ }^{23}$ Ibid., 341. She uses the phrase "De onkuische Sodomite vrucht." Lia van Gemert sees this choice of words as a potential reference to homosexuality. See "Hiding" esp. 23. Grabowsky does not address this specific poem but argues strongly against Van Gemert's readings of Lescailje.

24 Lescailje, Mengelpoezij, 340: "een Maagdeveêr, / Is even, als haar eer, zo teêr."

25 Ibid., 336: "die, die nooyt het licht aanschouden." 
ture on a trip, for instance, nature mourns for Van der Veer when absent, while the urban landscape of Amsterdam is populated by local deities who bow down before Van der Veer's mystical superiority, as if she were a queen on a progress. "On the Departure of the Famed Poetess Mistress Cornelia van der Veer" begins by describing the effect of her absence on Lescailje's own muse, but then moves to a communal perspective, asking "Who would not mourn her absence?"26 In this poem, the friend and the larger world respond identically to Van der Veer. The "YGod," God of the river IJ, is suffering while Van der Veer is gone, and he celebrates her triumphant return seated on his throne of mother of pearl, accompanied by trumpets and the joyful song of all the other water gods and goddesses. The second birthday poem features Apollo himself praising Van der Veer's poems while seated on the bank of the IJ. In contrast with the emphasis on their joint efforts as poets in the real world, these praise poems give Van der Veer semi-divine, royal status, and Lescailje takes on the role of humble subject and devotee to her poetry, whose task is to record Van der Veer's God-given virtues. In this romantic representation of a public sphere that gathers around a single female figure in the absence of religious, political, and social division, there is a delicate balance between humorous exaggeration and solemn reflection. Lescailje is making a playful and deliberate overstatement, creating a dream-like vision that is both serious in its presentation of Van der Veer as chosen by God and amusing due to the incongruity between the lofty pagan gods and their homely surroundings. In spite of this poetically productive tension, her poem is meant as real praise for Van der Veer and has actual implications for the literary environment in which she works, which has failed to see the importance of female writing. Lescailje makes, however tongue-in-cheek, the case that women's poems enlighten and unite those who read them.

Poetic use of names helps establish and legitimize the public importance of the female friend. Lescailje concludes her poem of welcome with

${ }^{26}$ Ibid., 331-32. The original title is "Op het vertrek van de vermaarde dichteresse Mejuffrouw Cornelia vander Veer." Lescailje asks, "Wie zou niet om haar afzyn treuren?" (332). In this and other poems, the two include extensive references to classical antiquity, contradicting their emphatic injunction against doing so. 
an appropriate gesture of adoration, speaking of her "Muse, who humbly lays her quill / Down before VEER." ${ }^{27}$ Van der Veer's poetry inspires and silences her fellow female poet at the same time. But even at this moment of poetic humility, there is a witty pun on Van der Veer's last name in the word "VEER" or feather, one that Van der Veer herself frequently used to suggest that she was meant to be a poet from birth. Both women repeatedly "rename" the other or pun on the other's name as a way of establishing a poetic identity that is not contingent on class, gender, marital status, or social approval. Thus, they envision a public sphere that is organized along the mystical lines of female virtue and religiously inspired art. In her opening praise poem to Van der Veer, "On the devotional poems by the pious and famous poetess Cornelia van der Veer," Lescailje writes that Van der Veer has elevated the art of poetry itself to the level of the truly divine:

The Art of Poetry received from VANDER VeER

An amaranthine praise and honor;

Since her spirit could ascend further

Than to the high Helicon,

Even above stars, moon, and sun;

To gain heavenly laurels,

Which now adorn her art so proudly,

From which virtue and Religion shines:

Because she gained from Angels' feathers

Her Feather, dipped in the holy bath

Of the everlasting water of life,

Which in her Poems we can see.

So is being prepared for her Poetry

A crown of immortality.

27 Ibid., 334: "Zangster, die haar veder / Leit voor VEER eerbiedig neder."

28 Ibid., 96: "De Dichtkunst kreeg door VANDER VEER / Een onverwelkb're lof en eer; / Nadien haar geest kon veerder stygen / Als op den hoogen Helikon, / Zelfs boven starren, maan, en zon; / Om hemelschen Lauwrier te krygen, / Daar nu haar kunst zoo fier meê praalt, / Waar uit de deugd en Godsdienst straalt: / Want zy verkreeg uit Eng'lepennen / Haar VEER, gedoopt in 't heilryk bad / Van 't eeuwigduurend levensnat, / Dat in haar Dichten is te kennen. / Dies word haar Poëzy bereid / Een Eerkroon van 
Here too, the capitalization and the pun on "VEER" place stress on the name as a transcendental signifier of poetic identity. The word "further" (veerder) is italicized because it also puns on Van der Veer's last name and alludes to Van der Veer's motto, "Ik tracht veERder" ("I try further"). Van der Veer, in turn, declares in "To the Artful and Sweet-flowing Poetess, Catharina Lescailje" that Lescailje is the true descendant of Questiers, announcing that "CATrien was reborn in Catharien." ${ }^{29}$ Playing on the name of the other, along with the pervasive repetition of names in titles of poems and elsewhere, establishes each woman's poetic credentials beyond doubt, placing her above and beyond the actual social and cultural hierarchy. Thus, the praise poems articulate an alternative society, in which everyone recognizes the spiritual power and superiority of the female poet, signaled by her name.

As noted above, private and public come together in the praise poems, which is not to say that private expression is absent but that there is no marking off of private emotion, no separation of public and private response, and no treatment of private emotion as prior to and distinct from public recognition. Rather, personal affection is formulated as entirely based on publicly disseminated poetry. This allows room for eroticism, primarily in reference to poems. Although the language of praise is often conventional, Lescailje and Van der Veer make their own embodiment an unproblematic aspect of their relationship and their virtuous femininity. This leads to startling shifts between high-flowing language and physical imagery, registers we would associate with publicity and privacy. For instance, mourning Van der Veer's temporary departure, Lescailje describes her as
A Sun who with her clear poems, And strength of elevated tone, Through which she received the laurel crown, Could often illuminate my spirit;

\footnotetext{
onsterf'lykheid." The poem's original title is "Op de stichtelyke vaerzen van de godvruchtige en beroemde dichteresse Cornelia vander Veer."

29 Ibid., 335: "Dus werdt CATRIen in CATHARIen berboren." The original title is "Aan de konstige en soetvloeijende dichteresse Catharina Lescailje."
} 
And in that godly art, Emerging, made me burn intensely And my mouth water for her friendship. ${ }^{30}$

Mixing ancient and Christian frames of reference, Lescailje uses the image of the sun to join both Apollo and Christ in Van der Veer, who is defined as a force of religious enlightenment. Yet, she follows this metaphor with a strong physical response to Van der Veer and her art. Similarly, Van der Veer writes in her "Complaint to the witty Katharine Lescailje," And though my ears itch after your delicious poems / Which outdo rose and carnation in her scents / Your muse remains absent, to me dear and welcome." ${ }^{11}$ Thus, these poems embody the idealized friend in the form of her poems, along with the reader of that poetry, whose watering mouth and itching ears suggest intimate, physical desire. In the poem welcoming her friend back from her journey, Lescailje describes this eroticism as not personal but collective: in Van der Veer's poems, "each letter is an alluring look, / Every word a spark of love," which has made the gods fall in love with her. ${ }^{32}$ The woman writer gives rise to a religious poetics, then, which, joined with the eroticism of her poems, gives her work private and public, spiritual and material significance; these opposing realms are not in tension with each other and are equally important. Given the dearth of lyric poetry by women about men in the Dutch Republic, such passionate expressions may, as Lia Van

30 Ibid., 331: "Een Zon die met haar held're dichten, / En kracht van een verheeven toon, / Waar door zy kreeg de lauwerkroon, / Myn geest kon menigmaal verlichten; / En in die goddelyke kunst, / Met voor te treên, deed yvrig branden, / En naar haar vriendschap watertanden."

31 Ibid., 348: "En schoon myn Ooren na uw leck're Vaarsen jeucken, / Die Roos en Anjelier, braveren in haar reucken, / Uw Sangheldin blyft wegh, my lief en wellecom." The original title is "Klaghte aan de volgeestige Katharine Lescailje." Paul Vincent translates these lines as "And though my ears for your fine verses twitch / That compete with rose and carnation to make our senses itch, / Your Muse is absent still, whom I would love to come." Thus, he tones down the playfulness of the itching ears and the sensuality of the original use of the adjective "leck're" (lekkere, delicious) to describe the poems. Cf. Women's Writing from the Low Countries, 301.

${ }_{32}$ Lescailje, Mengelpoezij, 333: "elk letter is een lonkje, / Yder woord een liefdevonkje." 
Gemert has suggested, provide us with information on real, lived same-sex experience, but they also ambitiously reformulate the meanings of female public identity to include an embodied female poet and reader at the center of an invented, harmonious public sphere. ${ }^{33}$

In these Dutch poems, the continuity between public and private, founded on the worship of the Protestant woman writer, is lost when friendship is subject to change. When friendship is threatened, the public sphere becomes again the actual, contemporary literary world, conflictridden, male, and monetary, a world in which female poetry has no place. At the same time, these poems negatively represent privacy as corrupted by this public sphere. The "Complaint" by Van der Veer begins with three direct questions on the state of their friendship:

How does it stand, KATHARIEN, with our friendship?

Does she resemble the common kind, which most frequently is lost?

Or do you feel, brave virgin, that I have not given full measure To you, in exchange for the money received? ${ }^{34}$

Friendship has been debased to the level of the corrupt marketplace, becoming a "common" matter of monetary exchange. Van der Veer expresses her hope that a promised visit from Lescailje will undo her agterstal or "unpaid debt." ${ }^{35}$ In other words, what she names "that great work" of friendship is degraded to the point where it has become a matter of potentially uneven payment between individuals. ${ }^{36}$

33 See Van Gemert, "Hiding"; also, Grabowsky, "Vrouwenzucht," 143-49. In her survey of lyric poetry by Dutch women, M. A. Schenkeveld-van der Dussen notes how few focus on men. See De geheimen van bet vrouwelijk bart: Nederlandse vrouwelijke auteurs over de liefde in lyriek en roman (1600-1840) (Amsterdam: Koninklijke Nederlandse Akademie van Wetenschappen, 2001) and "Liefdestalen van vrouwelijke auteurs," Literatuur 12 (1995): 335-40.

34 Lescailje, Mengelpoezij, 347. "Hoe isset Katharien, met onse vriendschap g'legen? / Slagt sij 't gemeene goedt, dat meest verloren gaat? / Of waant gy, braave Maaght, dat ik geen volle maat / Aan u gegeven beb, voor 't geldt daar voor verkregen?"

35 Ibid., 348. The monetary implications of the word are not captured by Vincent's translation, "harm" (Women's Writing from the Low Countries, 299).

36 Ibid., 347. Van der Veer calls friendship "dat grote werk." 
Both Van der Veer and Lescailje have lost their public presence in this poem, and their privacy is represented in poetic metaphors that suggest corruption and a loss of voice. Van der Veer compares her own desire for Lescailje's friendship to Polyphemus's fruitless chase of Gallathea as well as Dido's sorrow for Aeneas. These references to ancient literature might be read as elevating an ordinary moment of jealousy, but they also signal the undoing of female friendship by alluding to the kind of writing the two rejected in favor of religious poetry. Faced with potential infidelity, Van der Veer expresses her fruitless desire in a male register rather than a distinct female one. She goes on to complain of her own "dim brain," a description that does not appear as conventional modesty but as self-doubt. She says that at a future visit, she hopes she will find Lescailje not like "an unlettered book / In which I can read you neither Friend nor Foe." The editors of Met en zonder lauwerkrans explain that the phrase "unlettered book" refers to a book without dedication, but it may also be taken literally to mean an empty book from which poetry has been erased..$^{37}$ Her desire to read Lescailje and her poetry remains, but her fear is that Lescailje has become illegible, as the decline of friendship is imagined to silence both women poets. Rather than celebrate her desire for Lescailje's art, the pleasure she receives from it is finally described as "strange." ${ }^{38}$ It is no longer phrased in religious, collective terms but rather presented as an inexplicable emotion with no positive spiritual effect. This poem does much more to create the impression of a private relationship than the praise poems, but it figures that privacy as negatively penetrated by the logic of the public marketplace.

To restore the friendship, Lescailje re-emphasizes its spiritual, public significance. In her apology, she explains that in the face of Van der Veer's presence and art, she felt as if her writing was inadequate. Thus,

${ }^{37}$ Ibid., 348. The original for "dim brain" is "dom verstandt." She hopes Lescailje is not like "een ongelettert Boek, / Waar in ik u Vrindin, noch Vyandin ken lesen." Vincent translates it as "an undedicated book" (Women's Writing from the Low Countries, 299), and the footnote reads, as in Met en zonder lauwerkrans, ed. Schenkeveld-van der Dussen, et al., "A book in which Lescailje has not written a dedication" (Women's Writing from the Low Countries, 300; Met en zonder, 361).

${ }^{38}$ Ibid., 348. She calls the pleasure she receives from reading her poetry "sonderlinch." 
she resumes her role as humble admirer, returning Van der Veer to her place as a god-like poet. The "true fire of friendship," she argues, is like the sun itself, at times afraid to break through, but eternal and immortal, not subject to the vagaries of individual emotion. ${ }^{39}$ Friendship now has nothing to do with physical presence: "Do you think, Cornelia, adorned with so many gifts, / That I don't contemplate you even though you hide your face? / I see you without seeing, and praise your glorious light." ${ }^{\prime 40}$ Under the pressure of a perceived betrayal, then, female friendship becomes fully Platonic, a spiritual, idealized relationship, unaffected by time, place, and even death. The duality of the intimate eroticism and spiritual adoration that marked the earlier poems has been left behind, making for a disembodied femininity that maintains its status as a fitting object for adoration.

These Dutch friendship poems, taken together, claim a central position for the woman writer. But they stake this claim on a fantasy world in which there is no divisive public sphere, a world that is founded on absolutist political principles of mystified female authority and universal consent. In such a society, the female poet has the kind of spiritual presence attributed to monarchs, under whose aegis all unite without question. This model is capable of accommodating a physical presence for women, as the poems are said to arouse eroticism and desire in the reader. In its perfect state, friendship is unaffected by political controversy, social status, birth, and gender, and becomes pure desire for the other, for her perfect art and its unquestioned public function. However, in the absence of perfect friendship, the existing public realm gives rise to a private self that is characterized by silence, loss, and lack of status. Such betrayal is not truly overcome in the final poems of the series. Instead, they return to praise but purge it of its eroticism, making for a safer platonic version of female friendship.

39 Ibid., 350. The phrase is "waare vriendschapsvuur."

40 Ibid., 350. "Waant dan Cornelia, versierd met zo veel gaaven, / Dat ik u niet beschouw al schuilt gy uw gezicht? / Ik zie u zonder zien, en roem uw heerlyk licht." Heerlyk is a complex word, with meanings that range from the religious to the social (with "beer" referring to lord) and the physical, best translated as "delicious." 
Many of the friendship poems by Katherine Philips (1632-1664) offer thematically similar representations of female friendship. She calls friendship " $[t]$ hat noble flame," in a phrase close to Lescailje's, although the word "noble" shifts us from truth, with its religious overtones, to social status, defined as essence. ${ }^{41}$ Philips's work gives evidence of an intense interest in issues of class and status that are not present in the Dutch poems. Her father was a wealthy cloth merchant in London, while her mother had, like Lescailjés family, prominent political, literary, and especially Puritan connections. She was educated at Mrs. Salmon's boarding school for girls, described as Presbyterian in orientation. ${ }^{42}$ By her mother's third marriage and subsequently her own, Philips gained gentry status, which brought her into contact with members of the Welsh and national elite; her husband, James Philips, was a moderate parliamentarian. ${ }^{43}$ Philips's marriage with a parliamentarian made her royalist friendship poetry perhaps more controversial than for the unmarried Dutch women, but, socially, she also stood to gain from her writings to friends. According to Barash, the poems to Anne Owen, for instance, won her particular social advantages: Owen's family was well-connected, and, as a potential matchmaker for Owen, Philips could use her friendship with Owen to cement her ties with Charles Cotterell, a prominent courtier, who was instrumental in saving Philips's husband from political and personal disaster after the Restoration and who eventually would be in charge of the posthumous publication of Philips's work. ${ }^{44}$ Philips's politics also meant that her friendship poems

${ }^{41}$ Katherine Philips, The Collected Works of Katherine Philips, the Matchless Orinda, vol. 1, ed. Patrick Thomas (Stump Cross: Stump Cross Books, 1990), 150. All references are to this edition.

42 Elizabeth Hageman, "Katherine Philips," Dictionary of Literary Biography, vol. 131 (Detroit: Gale, 1993), 202-14, esp. 202-3. See also, for another up-to-date description of her life, Warren Chernaik, "Katherine Philips," Oxford Dictionary of National Biography (Oxford: Oxford University Press, 2004), 59-63.

${ }_{43}$ Hageman describes him as "a relatively apolitical man devoted more to the ideals of public service than to the nuances of partisan politics" ("Philips," 205).

${ }^{44}$ Barash, English Women's Poetry, 76. It is difficult to know the exact sequence of events when it comes to the attempt at matchmaking. As Sarah Prescott has shown, Philips's social position in Wales is more complex than Barash acknowledges, since her mother married into the most prominent family in the Welsh region to which they 
could help establish contacts with other royalists and thus gain her much needed outside backing for a set of ideas that were, within her family, considered controversial.

Thus, within her coterie, Philips's poems serve a social and political purpose beyond the articulation of private emotion, partially modifying the conventional emphasis in friendship discourse on likeness and allowing us to see them as also akin to poems to patrons; they forged useful connections and confirmed Philips's status within her social circles. By contrast, these advantages are not immediately apparent in the case of the two Dutch writers, who were effectively social equals. When they wrote poems to each other, Van der Veer was the older, more established poet, with a reputation to uphold. Yet, Van der Veer would have profited from Lescailje's status as a book publisher and from her many contacts. Neither woman, therefore, was in a position of superiority to the other. Instead, Lescailje and Van der Veer imagine a cultural climate in which their virtue and religious superiority outweigh their middling, unmarried status and gender. Since we find comparable forms of excessive praise for the female friend in Philips and in Lescailje and Van der Veer, it is difficult to attribute these only to the social inequalities between Philips and Owen or to the practical benefits Philips might have received from writing them.

Certain aspects of Philips's friendship poems suggest that they could be read as having primarily private rather than public significance: they are addressed to a small circle of socially privileged individuals and refer obliquely to specific events, using pseudonyms for real individuals. Although Van der Veer at one point limits her readership to those who share her religious beliefs, the Dutch poems are not as openly exclusivist as Philips's poems, for which the ideal intended readership seems to consist only of the "Society of Friendship" itself. While the punning on names is readily understood by readers of the Dutch poems, pseudonyms are only decipherable by those within a particular circle. They are drawn from royalist and classical sources that would be recognizable to a well-read readership, but the people to whom they refer would remain unidentified

moved. See "'That private shade wherein my Muse was bred': Katherine Philips and the Poetic Spaces of Welsh Retirement," Philological Quarterly 88.4 (2009): 345-64. 
to many readers outside the coterie. At the same time, the use of pseudonyms in coteries serves, Margaret Ezell has argued, to "give coherence to a specific social and literary environment ... to enhance and to announce the values and characteristics upheld by the group." 45 Ezell thus suggests the complexity of the relationship between public and private in these poems: while they are intended to strengthen relationships within a particular "social and literary environment," itself a limited public sphere (or counterpublic) within the larger public sphere, they not only affirm and articulate the norms of the group but also "announce" them to a wider readership, whether through manuscript circulation or through print.

The choice of the "Society of Friendship" for Philips's circle points to the interrelation of public and private and the simultaneous withholding and granting of access to her readers. Since the range of meanings for "society" includes both individual relationships and larger affiliations, the Society of Friendship combines the idea of close personal friendship with political association and spiritual as well as moral affiliation. A few months after Philips's death, Sir Edward Dering wrote of the Society that it was designed

to unite all those of her acquaintance, which she found worthy, or desired to make so ... into one societie, and by the bands of friendship to make an alliance more firme then what nature, our countrey or equall education can produce: and this would in time have spread very farr, $\&$ have been improved with great and yet unimagind advantage to the world: for it would have been of great use sure, to show the world that there were satisfactions in vertuous friendship farre transcending all those delights, which the most specious follyes can tempt us with. ${ }^{46}$

45 Margaret Ezell, "Reading Pseudonyms in Seventeenth-Century English Coterie Literature," Essays in Literature 21 (1994): 14-25, 22-23.

46 Patrick Thomas, "Introduction," in The Collected Works of Katherine Pbilips, the Matchless Orinda, vol. 1, ed. Patrick Thomas (Stump Cross: Stump Cross Books, 1990), 11. Thomas quotes Sir Edward Dering from his manuscript Letter-book, University of Cincinnati Library, Phillipps MS 14392. 
From creating bonds between a select group of individuals, already worthy or potentially worthy, Philips's ambition, according to Dering, was to form a society in a much larger sense, bound not by birth, nation, or education but by spiritual ties of friendship. The representation of friendship between women thus oscillates in Philips's work between the elite world of social privilege, passion, and privacy and the larger world of religion, politics, and morality. It represents a simultaneous withdrawal into the coterie and entry into a public sphere that is conceived of as reformed by affinity. Thus, her poems manifest themselves as more private than but equally publicly ambitious as the friendship poems by Lescailje and Van der Veer, which claim a spiritual function for the female poet with similar insistence. The political instability in both countries allowed for the imagined replacement of male authority and conflict with female-inspired, romantic models of social harmony.

The tension between announcing poems as personal and expressing a desire for public significance can be found everywhere in Philips's friendship poetry. On the one hand, poems such as "Content," describe friends as those "Who cannot wish for other things / Then Privacy and friendship brings." 47 Privacy, here, is closely aligned with friendship, and there is no need for public recognition. At times, she depicts female friendship as an escape from the world, expressing a desire for withdrawal, whether it is to a pastoral setting such as a bower in "A retir'd friendship" or to an inner space free of politics. In "Lamitié: To Mrs M. Awbrey" the speaker tropes friendship in terms of secrecy and privacy: "Thy heart locks up my secrets richly set, / And my brest is thy private cabinet." ${ }^{\prime 48}$ In this case, inner space provides a refuge from a world in which "Envy, pride and faction play their game," and privacy is defined as secrecy, the predominant sense in which it was used in the period. ${ }^{49} \mathrm{On}$ the other hand, these references to friendship as central to retirement may also be read in a public light. Andrew Shifflett has discussed the influence of Stoicism on the literature of retirement in the seventeenth century, calling it "the publication of privacy, the commer-

\footnotetext{
47 Philips, Collected Works, 94.

48 Ibid., 142.

49 Ibid., 142. Longfellow, "Public, Private, and the Household," 315.
} 
cialization of the withdrawn personality" and a literature that is very much concerned with "community," aimed at displaying virtue and commenting on public conflict. ${ }^{50}$

Not surprisingly, then, Orinda repeatedly expresses a desire to reveal her friendships to the larger world. In "Friendship's Mysterys," she says to Lucasia, "To the dull, angry world let's prove / There's a religion in our Love." ${ }^{\text {" I } 1}$ " "To my Lucasia, in defence of declared friendship," she pleads,

O! my Lucasia, let us speak our Love,

And think not that impertinent can be,

Which to us both does such assurance prove

And whence we find how Justly we agree. ${ }^{52}$

In these poems, Philips envisions a clearer separation between private emotion and public presence than the Dutch women. Although Orinda feels friendship should influence the larger world, at times she treats the private friendship as prior to its public emergence, which is presented as a decision to "come out." Lescailje and Van der Veer, by contrast, conceive of their friendship from the start as based on their poems; for them, public and private are at one, in spite of their concerns about attacks from male readers, until friendship falls away from the ideal.

The actual public sphere in the Dutch poems is male, heathen, and threatening to female writers; its equivalent in Philips is male, immoral, in decay, and explicitly marred by war. What she calls "the world" is "false," "dull, angry," "brutish," and characterized by "quarrelling for Crowns." In "To (the truly competent Judge of Honour) Lucasia, upon a scandalous

50 Andrew Shifflett, Stoicism, Politics, and Literature in the Age of Milton: War and Peace Reconciled (Cambridge: Cambridge University Press, 1998), 4-5. Shifflett discusses Philips's play Pompey as a neo-Stoic reflection on the political virtue of clemency; while he does not address her retirement poetry specifically, his discussion of others, including Marvell and Milton, has clear relevance to her poems.

51 Philips, Collected Works, 90.

52 Ibid., 153.

53 Ibid., "Friendship's Mysterys" (90), "Content" (91), "Friendship" (150), and "A retir'd friendship" (97). 
libell made by J. Jones," Philips presents the reader with a negative representation of a public sphere as dominated by "opinion" and marked by a prostitution of honor, a sphere into which Jones threatens to draw the speaker. The poem refers to an attempt to publish Philips's poem "Upon the double Murther of K. Charles I" to discredit her husband. In response, Philips formulates a concept of honor that is not subject to general approval but only to the single, pure judgment of the female friend. At the same time, Philips locates honor within the self: "honour is its own reward and end, / And satisfyed within, cannot descend / To beg the suffrage of a Vulgar tongue," making it a private matter only. ${ }^{54}$ Nonetheless, the speaker's final appeal "unto the knowing few" and her desire for Lucasia's judgment show that honor still requires the approval of others. ${ }^{55}$ Barash argues that it is Lucasia's honor that saves Orinda's, by giving "the material situation" spiritual and divine significance. ${ }^{56}$

To properly reform the world, Orinda writes in "Lucasia," the public and the private must be in harmony:

Not to obleige Lucasia by my voice,

To boast my fate, or Justify my choice,

Is this design'd; but pitty does engage

My pen to rescue the declining age.

For since 'tis grown in fashion to be bad,

And to be vain or angry, proud or mad,

(While in their vices onely men agree)

Is thought the onely modern gallantry;

How would some brave example check the Crimes,

And both reproach and yet reform the times?

Nor can morallity it self reclaime

54 Ibid., 115.

55 Ibid., 116.

56 Barash, English Women's Poetry, 73. See also Gray, Women Writers and Public Debate, 130, where she argues that the contradictory relationship between the speaker and the common public (which is needed to give her honor currency) is resolved by a turn to Lucasia. 
Th'apostate world like my Lucasia's name. ${ }^{57}$

The complaints about the public realm represent a critique of "fashion" and "modern gallantry," suggesting that a reformation of courtliness along the lines of female virtue is needed. The use of the word "apostate" suggests that the decline of the world should be conceived of in religious terms, recalling a similar emphasis on religion by Van der Veer and Lescailje. Yet here too it is difficult to gauge the level of playfulness involved. Philips boldly uses religious terms where they might well be considered inappropriate, creating a deliberate overstatement for the sake of courtly entertainment. Simultaneously, she proposes in all seriousness that the public sphere can be reformed by a renewal of faith in female virtue. As in the Dutch poems, Philips imagines a public sphere characterized by conflict that unites in adoring a female figure. Thus, we might say, she too articulates an absolutist vision of a society in which single individuals take center stage and create consensus through vaguely defined virtue.

Aside from such fundamental similarities, there are differences too. Lescailje's praise poems to Van der Veer are accompanied by responses from her friend, which make theirs a collaborative effort to formulate their values and represent authorship as key to the reforming power of virtuous femininity. This collaboration, when compared with Philips's work, highlights the degree to which Philips constructs a silent female love object like much male love poetry. Lescailje and Van der Veer imagine a more active role for the virtuous female at the heart of their utopia, whereas Philips contrasts the actively writing Orinda with the noble, but passive presence of Lucasia, whose goodness is mystified even more than its counterpart in the Dutch poems. Even so, the kind of adoration expressed for Lucasia is clearly comparable to Lescailje's praise poems. As is true of the devout virgin writer in the Dutch poems, Lucasia is constructed as the panacea to a contemporary society torn apart by religious, political, and social divisions, magically silencing the kind of debates that made up the emerging public sphere.

57 Philips, Collected Works, 103. 
These poems are conflicted in how they represent these virtuous friends: as examples to be imitated or as beyond representation. This paradox marks courtesy literature more generally. ${ }^{58}$ The key moral terms used to describe "Lucasia" are humility, modesty, proportion, comeliness, reason, and intuition, terms that are closely aligned with the ideal female sketched by Lescailje and Van der Veer. Such qualifications point to conventional upper-class ideals of femininity and create the impression that such goodness is within reach of women generally. At the same time, the speaker places Lucasia's virtue in the Platonic realm of ideas rather than in the material world, elevating her, like Van der Veer in Lescailje's praise poems, to the point of deification and abstraction. ${ }^{59}$ Orinda too compares her ideal female friend to the sun: "she now life, and then doth light dispence, / But is one shining orb of Excellence." ${ }^{60}$ Yet the poem concludes, "No pen Lucasia's glorys can relate, / But they admire best who dare imitate." Thus, the poem asks us to perceive Lucasia's worth as both open to imitation (and thus a matter of merit) and mystically beyond reason and language (and therefore a matter of innate virtue and religious value); this type of royalist, courtly praise demonstrates conceptual affinities with the Calvinist notion of the single female poet chosen by God, who serves to reform others.

The only way in which poetry can provide "coppys" of Lucasia is through emphasizing her name, which becomes a transcendental signifier as much as the female poet's name is in the Dutch poems. ${ }^{62}$ For Van der Veer and Lescailje, renaming, punning on, and repeating the name of the friend allow them to establish her mystical significance beyond question. The emphasis on the name Lucasia is equally strong in "To the excellent $M^{\mathrm{rs}} \mathrm{A}$.O. upon her receiving the name of Lucasia, and adoption into our

58 On this paradox, see Frank Whigham, Ambition and Privilege: The Social Tropes of Elizabethan Courtesy Theory (Berkeley: University of California Press, 1984).

59 Easton calls the Platonic elevation of Lucasia in Philips's poetry a "strategy of denial" of troubling same-sex eroticism and politics ("Excusing the Breach of Nature's Laws," 5).
60 Philips, Collected Works, 104.
61 Ibid., 105.
62 Ibid., 104. 
society." Here too, Philips stresses the restorative power of Lucasia's name, which not only turns Mrs. A.O. into a religious icon but also elevates her admirers and members of the Society of Friendship. The act of renaming Anne Owen is especially important since it removes her name's patriarchal basis in the name of either father or husband and shifts it into a fictional, feminine realm. It also highlights the power of writing: "Lucasia," displacing "Owen," signifies the mystical feminine ideal. This poem is even vaguer than "Lucasia" on Lucasias precise virtues, articulated in terms of the sun, the brightness of her mind, and her splendor, which "diffuses glorys every where." Instead, Orinda seems more concerned with relating how the Society, whose membership remains unidentified, is made "compleat" by admitting Lucasia. ${ }^{63}$ The name of Lucasia compels those outside the Society to acknowledge its superiority and renders the conventional means of measuring power insignificant:

Nay, the dull World must now confess

We have all worth, all happiness.

Annalls of State are triffles to our fame,

Now 'tis made sacred by Lucasia's name. ${ }^{64}$

The Society has become "A Temple of divinity," which, the speaker predicts, will be canonized and visited by pilgrims after their death. ${ }^{65}$ These compliments to Owen suggest that individual and social morality will be reformed once the social order is reconstructed along lines of female virtue. As Gray and Barash argue, private affiliations are used to suggest public reform, but the key point seems to me that proper femininity is shown to be of such superiority that it transcends the contentious public sphere and dissolves the boundaries between personal and collective response.

63 Ibid., 101-2.

64 Ibid.

65 Ibid., 102. Mark Llewellyn reads the religious tropes as suggestive of Philips's presentation of friendship as a "secular religion." See "Friendship, Poetry, and NeoPlatonic Thought in Seventeenth-Century England," Pbilological Quarterly 81.4 (2002): $441-68,450$. 
In this impersonal representation of friendship, the female body has a complex role to play. Critics such as Wahl and Valerie Traub have addressed the question of the female body and eroticism in Philips's work. ${ }^{66}$ What is notable in comparison with her Dutch counterparts is the variety of strategies adopted by Philips to allow for erotic expression and female physicality, however obliquely. A major tactic is the Platonic substitution of souls for bodies, which enables an erotic discourse of mingling, touch, and sensuality, much like the substitution of poems for bodies that permits attention to physical details in Van der Veer's and Lescailje's work. Such substitutions allow these women to publicize intimate private bodily signs, while maintaining the impression of innocence and virtue. For example, in "To my Lucasia, in defence of declared friendship," for instance, Philips writes,

Although we know we love, yet while our soule

Is thus imprison'd by the flesh we wear,

There's no way left that bondage to controule,

But to convey transactions through the Eare. ${ }^{67}$

Philips's Platonic dissatisfaction with embodiment as "that bondage" turns her to the ear, language, and poetry as means of transmitting love. For Wahl, Philips "suggests the insufficiency of such aurality to compensate completely for the deficiencies of the flesh," but we may also see Philips's gesture as a culturally important step on the way to erotic expression of fuller embodiment for women. ${ }^{68}$ Indeed, Traub has noted that in many poems Philips conflates body and spirit, overcoming their philosophical separation in particular when her speaker laments the absence of the beloved. ${ }^{69}$ Whether or not we see such strategies as revealing frustration with the cultural barriers to more open female eroticism, both Philips and Van der Veer point to the ear as a possible site of amorous exchange and

66 Valerie Traub, The Renaissance of Lesbianism in Early Modern England (Cambridge: Cambridge University Press, 2002), chap. 7, and Wahl, Invisible Relations, chap. 3.

67 Philips, Collected Works, 154.

68 Wahl, Invisible Relations, 151

69 Traub, Renaissance of Lesbianism, 302. 
poetry or language as a substitute for the female body, sanctioning the expression of desire within the context of an idealized, morally praiseworthy, and spiritual female friendship. Such expression, I would argue, is possible only in a context in which public and private are in perfect harmony and not seen as opposing spheres. In other words, the presence of eroticism does not yet conflict with the assertion of public significance. In that sense, perhaps surprisingly, these poems are congruent with Alan Bray's argument in The Friend that it was not until late in the seventeenth century that respectable friendship between men lost its erotic and physical component and homoeroticism came to be treated as a perversion. Until that point, eroticism and civic ethics could be found side by side in friendship discourse. ${ }^{70}$ Bray himself does not find the same kind of representation of friendship in work by women, and Lorna Hutson has persuasively argued that the omission of women from Bray's account is due to the fact that women first needed to make friendship signify as publicly ethical. ${ }^{71}$ Indeed, Hutson sees it as Philips's greatest achievement that she appropriated the ethics of male friendship for women. While this is a persuasive argument, I suggest that the eroticism in the female friendship poems by both Dutch and English women also evoke the idea of the "gift of the body of the male friend" as articulated in Bray. His work reminds us that these poems are situated in networks of gift giving, and, along with the poems, we might see the bodily presence of both poet and friend in Philips and the Dutch poems as another type of gift giving.

Aside from these idealizations, Philips's representations of friendship explore in depth the psychological, social, and cultural consequences of marriage, jealousy, and betrayal. As is true for Van der Veer's "Complaint," the darker poems addressed to Rosania (Mary Aubrey) and Regina Collier tend to be more directly concerned with private emotion and come closer to articulating a private subjectivity. ${ }^{72}$ The decline of friendship, a betrayal

70 See The Friend (Chicago: University of Chicago Press, 2003), esp. chap. 6.

71 Lorna Hutson, "The Body of the Friend and the Woman Writer: Katherine Philips's Absence from Alan Bray's The Friend (2003)," Women's Writing 14, no. 2 (2007): 196-214.

72 Penelope Anderson argues compellingly for the political significance of the poems of betrayal in terms of people's shifting allegiances in the period. See "Friendship 
of those values that the later poems to Lucasia articulate, introduces the evils of the corrupt public sphere into essentially personal relationships rather than showing a symbiosis of public and private. In "Injuria amici" (addressed to either Rosania or Regina), the speaker describes the destructive power of the former friend as affecting both friends:

And you appeare so much on ruine bent,

Your own destruction gives you now content:

For our twin-spirits did so long agree,

You must undoe your self to ruine me.

And, like some frantique Goddess, you'r inclin'd

To raze the Temple where you were enshrin'd;

And (what's the miracle of Cruelty!)

Kill that which gave you imortallity. ${ }^{73}$

The public edifice of adoration, the temple, is devastated by the selfabsorbed woman, whose betrayal is figured as a kind of mythic madness, which acts in disregard of the larger benefits that spring from the friendship. The speaker tells the addressee that "Glorious Friendship, whence your honour springs, / Ly's gasping in the croud of common things," reminding her that her own status, which is beyond question in the Lucasia poems, has become like the negatively troped larger "common" world, akin to Van der Veer's reference to "common" friendship. ${ }^{74}$ In "To Rosania (now Mrs Mountague)," Orinda complains that "Devided Rivers loose their name," pointing to the centrality of the name of the female friends in establishing their spiritual role. ${ }^{75}$ Once the name is lost, the public self is lost too; in this case the female self has become submerged under the husband's name.

Multiplyed': Royalist and Republican Friendship in Katherine Philips's Coterie," in Discourses and Representations of Friendship in Early Modern Europe, 1500-1700, ed. Daniel T. Lochman, Maritere López, and Lorna Hutson (Farnham: Ashgate, 2011), 131-45.

${ }^{73}$ Philips, Collected Works, 124.

${ }^{74}$ Ibid., 124; Lescailje, Mengelpoezij, 347.

75 Philips, Collected Works, 128. See also Anderson, "Friendship Multiplyed," 135-37. 
Women who betray friendship have individual agency but not the kind of role envisioned for the idealized woman. Animosity, then, ruins the public significance of friendship, allowing the public world to demean what is now strongly signified as private emotion.

Privacy, then, has a complex relationship to the public realm in Dutch and English friendship poems by women and is often, though not always, articulated in absolutist language. In their praise poems Lescailje, Van der Veer, and Philips imagine a world in which public and private are continuous, to such an extent that communal adoration of the friend coexists easily with personal feelings of erotic desire. In that sense, the poems hark back to a time when authority was absolute, located in virtue, and, in the absence of a clear separation between public and private, women could be imagined as taking a place at the center of a harmonious public realm. As a separate category, the private emerges at negative moments of fissure in these poems, either as a desire for retreat from the existing, conflicted public sphere or as a response to a betrayal of friendship by the friend. At such times, the private sphere is defined in negative terms as a place of loss of status and lack. These similarities are remarkable in light of two crucial differences between Philips and her Dutch counterparts: one is the clear political affiliation of Philips and the other is her marital status. While Philips as a royalist would be expected to idealize a public realm ruled by a female power that is absolutist, it is much less certain why Van der Veer and Lescailje, who had shifted in allegiance from the regents to the Stadtholder, would express themselves in those terms. That they did, I believe, means that we need to reassess Philips's work as well; we need to consider the possibility that her royalism is only part of the explanation for the specific form that her idealization of the friend takes. That all three women envisaged a perfect public world in absolutist terms suggests that those terms were available to women in countries with different political organizations and that they were more congenial to the idea of female power than the emerging public sphere itself.

The difference in marital status is equally important. Whereas Philips was married, and this was crucial to her public position as well as the presentation of herself as separate from her husband and family in her affiliations, Van der Veer and Lescailje were unmarried and could only be 
writers while single. The fact that Dutch women were expected to give up writing upon marriage is usually treated by historians as a consequence of their middling status, which meant that they would not have had much leisure time. But Lescailje was a working woman with a business to take care of. Therefore, the idea that writing had to be abandoned once married suggests that in spite of the gradual opening up of the printing press to Dutch women, there were still limits to their public voice. It is conceivable that this particular barrier to authorship arose from a fear of how female writing might reflect on the husband. Moreover, I want to suggest that this difference points to a stronger ideology of domesticity having already been formed in the Dutch Republic than in England, particularly for women who were not aristocratic or of the gentry. While unmarried women might display their writing talent as evidence of an elite education, married women were expected to remain quietly at work, taking care of their children, in a much more clearly delineated private space. Such a space, as set off from the public realm, can only be imagined negatively in the friendship poems of Van der Veer and Lescailje.

These friendship poems all feature the elevation of idealized femininity in religious and erotic language, the imagined absence of a contentious public sphere, the nostalgic representation of social harmony centered on a single figure, and the depiction of the betrayal of female friendship in terms that restrict women's agency to the private realm. These commonalities provide evidence that even in different countries, political circumstances, and social contexts, early modern women poets were articulating broadly similar ideas about the significance of female friendship. They also suggest that women were reacting to the consequences of the increased separation between public and private, leading to a playful celebration of a romantic world in which a single individual would, by virtue of her mystical superior essence, create social harmony. However differently placed these women were socially, religiously, and even politically, female friendship enabled them to envision a public presence for women that figured virtuous femininity as a source of unity and enlightenment. It seems women writers experienced the contentious public sphere as harmful and fantasized about a return to a simpler, more conservative social order in which public and private were one. Nonetheless, the emergence of the public sphere and 
the political upheavals that caused it enabled these women to make these statements, allowing them to go beyond their marginality and present themselves and their writings as culturally central. 